\title{
Detection of Cytotoxic Activity of Lectin on Human Colon Adenocarcinoma (Sw480) and Epithelial Cervical Carcinoma (C33-A)
}

Carmen Valadez-Vega ${ }^{1, *}$, Gerardo Alvarez-Manilla ${ }^{2}$, Leticia Riverón-Negrete ${ }^{3}$, Alejandro García-Carrancá ${ }^{4}$, José A. Morales-González ${ }^{1}$, Clara Zuñiga-Pérez ${ }^{1}$, Eduardo MadrigalSantillán ${ }^{1}$, Jaime Esquivel-Soto ${ }^{5}$, Cesar Esquivel-Chirino ${ }^{5}$, Roberto Villagómez-Ibarra ${ }^{6}$, Mirandeli Bautista ${ }^{1}$ and Ángel Morales-González ${ }^{7}$

1 Instituto de Ciencias de la Salud, Universidad Autónoma del Estado de Hidalgo, Ex-Hacienda de la Concepción, Tilcuautla, 42080 Pachuca de Soto, Hgo, Mexico;

E-Mails: jmorales101@yahoo.com.mx (J.A.M-G); zupec1@yahoo.com.mx (C.Z.-P.); eomsmx@yahoo.com.mx (E.M.-S.); mirandeli@hotmail.com (M.B.)

2 Ezose Sciences Inc, Pine Brook, New Jersey 07058, USA; E-Mail: gmanilla@ezose.com

3 Parasitología Experimental, Instituto Nacional de Pediatría, Mexico, D.F., Mexico;

E-Mail: riveron15@gmail.com

4 Laboratorio de Virus y Cáncer, Unidad de Investigación Biomédica en Cáncer. Instituto de Investigaciones Biomédicas, Universidad Nacional Autónoma de México and Instituto Nacional de Cancerología, Secretaría de Salud, Mexico, D.F., Mexico;

E-Mail: carranca@correo.biomedicas.unam.mx

5 Facultad de Odontología, Universidad Nacional Autónoma de México (UNAM), Mexico, D.F., Mexico; E-Mails: jaime_esquivel2003@hotmail.com (J.E.-S.); cesquivelch@gmail.com (C.E.-C.)

6 Instituto de Ciencias Básicas e Ingeniería, Universidad Autónoma del Estado de Hidalgo, Pachuca, Hidalgo, Mexico; E-Mail: Roberto_ibarrav@hotmail.com

7 Escuela Superior de Cómputo, Instituto Politécnico Nacional, México, D.F., Mexico; E-Mail: anmorales@ipn.mx

* Author to whom correspondence should be addressed; E-Mail: m.valadezvega@lycos.com; Tel.: +52-771-717-2000; Fax: +52-771-717-2000, extension 5111.

Received: 16 December 2010; in revised form: 25 February 2011 / Accepted: 28 February 2011 / Published: 2 March 2011

Abstract: Lectins comprise a heterogeneous class of proteins that recognize the carbohydrate moieties of glycoconjugates with high specificity. Numerous studies have 
shown that lectins are capable of recognizing specific carbohydrate moieties displayed by malignant cells or tissues. The present work was performed to investigate the effects of tepary bean (Phaseolus acutifolius) lectins on proliferation, colony formation, and alteration of DNA synthesis of human malignant cells. Tepary bean lectin showed dose dependent effects on the inhibition of viability as well as on colony formation in two human malignant cells lines (C33-A, Sw480); By contrast, tepary bean lectin only showed significant effects on DNA synthesis on Sw480 cells. Our results provide evidence of the anti- proliferative and cytotoxic effects of the tepary bean lectins on C33-A and Sw480 cells lines.

Keywords: lectins; tepary beans; cytotoxicity; tepary bean lectins

\section{Introduction}

Cancer represents the principal cause of death worldwide [1-3]. One strategy for cancer prevention is chemoprevention, which refers to the use of natural or synthetic substances to reduce the risks of developing cancer or to reduce the probability that cancer will recur. Chemoprevention research efforts started in the early 1980 s and have grown considerably since that time [4,5].

The cancer inhibitory action of natural products derived from plants has been confirmed in different animal tumor models [6,7] and has led to an increased emphasis on cancer prevention strategies in which these dietary factors may be utilized. Previous studies have demonstrated that natural agents can inhibit the development of human tumor cells in vitro [8-10].

Lectins are widely distributed in Nature, mainly in the plant kingdom, although they also occur in other organisms, such as animals and microorganisms [11-14]. Lectins are proteins or glycoproteins capable of agglutinating blood cells (erythrocytes or leukocytes) by interacting with specific carbohydrate residues in their cell membrane structure $[15,16]$. Although lectins have been known for more than a century, they became a focus of interest when it was found that they interact with specific carbohydrate residues on the cell membrane $[15,16]$. Given their specificity, lectins have the capability of distinguishing between different cell types, such as normal and malignant cells [17-19].

Many specific alterations in the structure of carbohydrates in the cell membrane have been observed in cancer cells, such as an increase in sialylation and modifications in the branching of complex carbohydrates; and even occasionally, the emergence of unusual structures [15,20]. For this reason, lectins represent a potentially useful tool to recognize specific alterations in transformed cells [14]. Aberrant glycosylation, which can be detected by lectin histochemistry, may predict the outcome of some tumor entities, such as in the case of aviscumine (recombinant mistletoe lectin) [21] and phytohaemagglutinin-L (PHA-L), which in addition, possess cytotoxic effects on malignant cells, and therefore may also be used in anti-tumor therapy [22].

Dietary lectins, such as wheat germ agglutinin (WGA), can inhibit cell growth of human breast cancer cells lines and may induce apoptosis after $30 \mathrm{~min}$ of incubation with tumor cells (Jurkat-R cells) [23,24]. Lectins from Solanum tuberosum, Triticum vulgaris, Lycopersicon esculentum and Helix pomatia has shown significant cytotoxic effects on transformed cell lines from conjunctive and 
corneal tissues [25]. Mistletoe lectins I,-II and III are highly toxic to several normal and malignant cells lines, thus inhibiting their proliferation [26]. Schwartz et al. [27] reported that concanavalin A (Con A), phytohaemagglutinin-L (PHA-L) and WGA inhibit DNA biosynthesis in pancreatic cancer cells. Other reports indicate that Griffonia simplicifolia agglutinin (GSA), Con A, and PHA-L had differential effect on cell growth on human colorectal cancer cell lines, by inhibiting their growth [28]. Plant lectins have also shown potential use in other diseases; for example, Galanthus nivalis lectin has shown inhibitory activity towards human immunodeficiency virus type I [29]; and Maackia amurensis, as well as Sambucus nigra agglutinins, have been shown to recognize specific receptors on influenza A viruses [30]. The aim of this study was investigate the cytotoxic effect of tepary bean (Phaseolus acutifolius) lectins (TBL) on human malignant cell lines using different in vitro proliferation and cytotoxic assays.

\section{Results and Discussion}

\subsection{Tepary bean lectin purification}

Lectin purification by fetuin-agarose affinity column chromatography showed that the lectin was recovered in one peak in fraction 34 when the column was washed with a solution of glycine- $\mathrm{HCl}$ $(50 \mathrm{mM}), \mathrm{pH} 2.8$. The hemagglutination assays employing human erythrocytes blood types $\mathrm{A}$ and $\mathrm{O}$ showed a high biological activity (Table 1); however only $10 \%$ of the hemagglutination activity measured in the crude extract was recovered. These results suggest that there are other fractions with hemagglutinating activity that did not bind to the fetuin affinity column. The purified fraction was employed for biological assays.

Table 1. Hemagglutination activity of the pure lectin from Phaseolus acutifolius.

\begin{tabular}{cccc}
\hline \multirow{2}{*}{ Lectin } & $\begin{array}{c}\text { Lectin } \\
\text { Concentration } \\
(\mathbf{m g} / \mathbf{m L})\end{array}$ & \multicolumn{2}{c}{ Human erythrocytes } \\
\cline { 3 - 4 } & 3.5 & Type A & Type O \\
\hline Tepary & $292.6 \pm 32.9$ & $36.6 \pm 4.3$ \\
\hline
\end{tabular}

Figure 1 shows the electrophoretic pattern on the reducing SDS-PAGE of the purified lectin showing a single band indicating the protein was purified, with a molecular weight of $31 \mathrm{kDa}$. The Native-PAGE showed a band with a molecular weight range between 132 to $153 \mathrm{kDa}$. This result suggests that the purified lectin is formed by four subunits.

\subsection{Effect of the TBL on the viability of human malignant cells}

The initial experiments were conducted employing the MTT assay to examine the cytotoxic effects of TBL. The cytotoxicity effects of tepary bean lectin on Sw480 and C33-A cells are shown in Figure 2. The results of this experiment demonstrated that TBL inhibited significantly the growth of Sw480 and C33-A cells lines. The $\mathrm{IC}_{50}$ of TBL for Sw480 cells was $84.2 \mu \mathrm{g} / \mathrm{mL}$ and more than $400 \mu \mathrm{g} / \mathrm{mL}$ for C33-A, indicating that Sw480 cells are more sensitive to the action of TBL. Thus, 0 , $10,25,50$ and $100 \mu \mathrm{g} / \mathrm{mL}$ of lectin concentration were chosen for the subsequent experimental assays. 
Figure 1. SDS-poliacrilamide electrophoresis pattern of the purified tepary bean (Phaseolus acutifolius) lectin. Lane 2, purified tepary bean lectin from fetuin affinity chromatography. Lane 1, molecular weight markers: myosin (200 kDa), $\beta$-galactosidase $(116 \mathrm{kDa})$, phosphorylase $(97 \mathrm{kDa})$, bovine serum albumin $(66 \mathrm{kDa})$, carbonic anhydrase $(31 \mathrm{kDa})$, trypsin inhibitor from glycine max $(21 \mathrm{kDa})$.

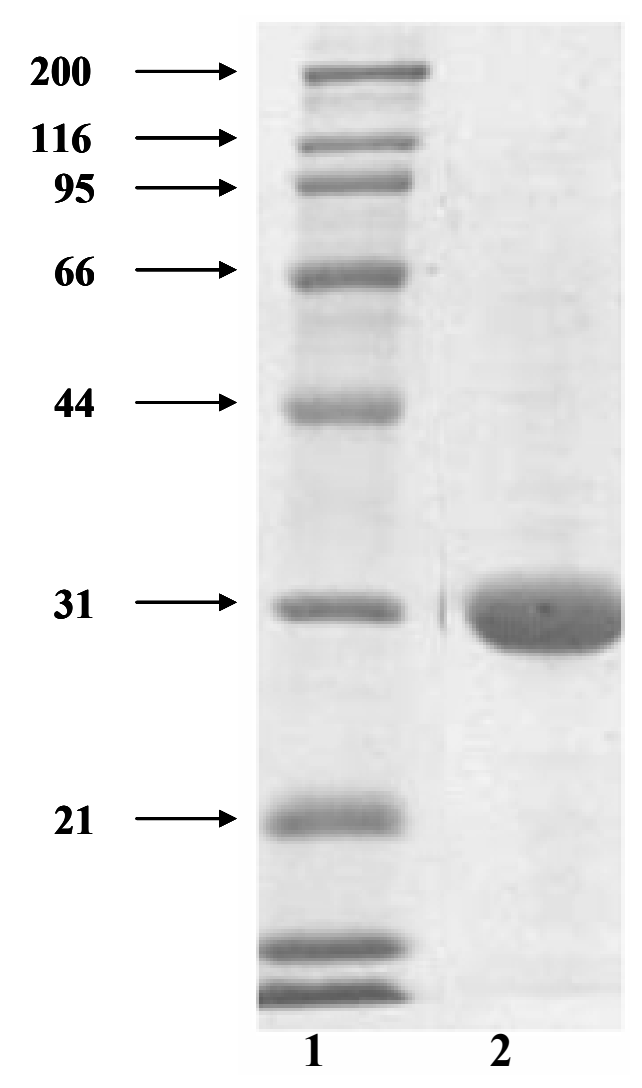

Figure 2. Effect of tepary bean lectins on the viability of human malignant cells lines. Cells (C33-A, SW480) were exposed to the indicated concentration of tepary bean lectins for $24 \mathrm{~h}$. The viability of cells was determinate as described in the Experimental section. Results are presented as the percentage of viable cells (untreated cells was considered as $100 \%$ of viability). C33-A $\longrightarrow$ SW480 $\quad$ \.

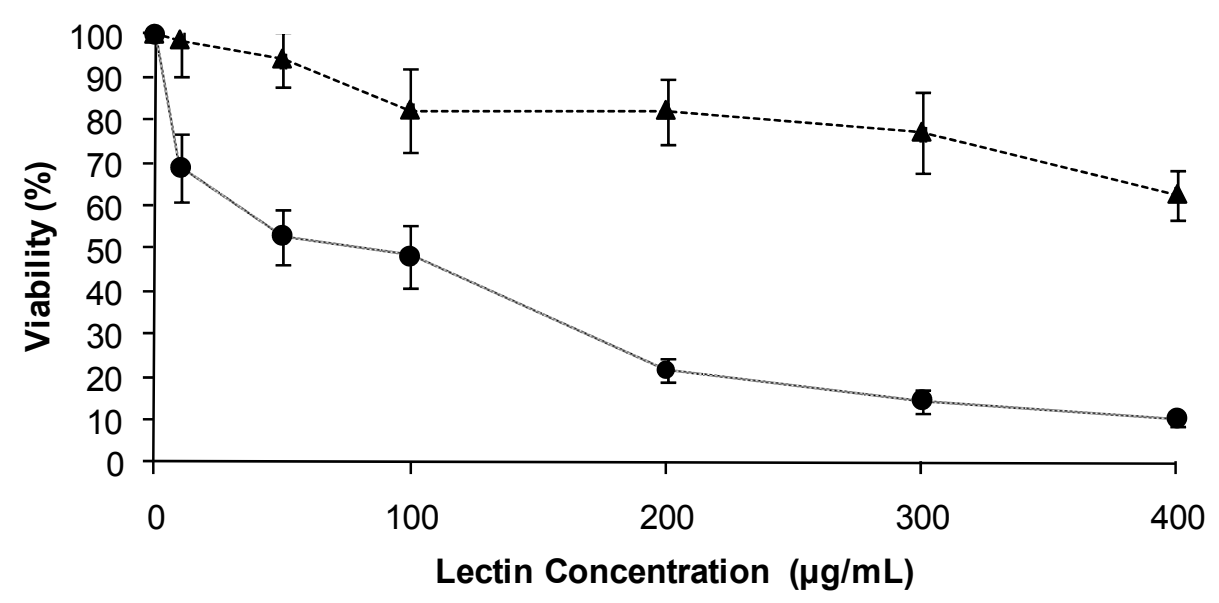




\subsection{Cytotoxic effect of TBL in human malignant cells}

The effect of TBL in malignant cells was evaluated using a radiolabeled ${ }^{3}[\mathrm{H}]$ thymidine assay. The data (Table 2) shows a dose dependent effect in both cell lines, so that increasing the concentration of lectin (TBL), decreased thymidine incorporation, suggesting a decrease in cell proliferation, although the effect is greater in C33-A cells lines, on the other hand, at $100 \mu \mathrm{g} / \mathrm{mL}$ shows an elevation in thymidine incorporation, which is associated with increased proliferative capacity of cells.

Table 2. Effect of tepary bean lectin on DNA synthesis in human malignant cells.

\begin{tabular}{ccc}
\hline \multirow{2}{*}{ Treatment } & \multicolumn{2}{c}{ DNA } \\
\cline { 2 - 3 } & (\% incorporation 3[H] thymidine) \\
\hline Control & $100 \pm 10.56$ & C33-A \\
$10 \mu \mathrm{g} / \mathrm{mL}$ & $71.3 \pm 5.93$ & $100 \pm 11.06$ \\
$25 \mu \mathrm{g} / \mathrm{mL}$ & $66.7 \pm 6.19$ & $42.6 \pm 11.35$ \\
$50 \mu \mathrm{g} / \mathrm{mL}$ & $59.7 \pm 5.43$ & $23.6 \pm 12.08$ \\
$100 \mu \mathrm{g} / \mathrm{mL}$ & $33.4 \pm 18.77$ & $21.2 \pm 13.47$ \\
\hline
\end{tabular}

Cells were exposed to the indicated concentration of lectins for $24 \mathrm{~h}$, after with ${ }^{3}[\mathrm{H}]$-thymidine

\subsection{Colony formation}

Colony formation assays were carried out to examine the effect of TBL on the ability to form colonies. Sw480 and C33-A cells were incubated with TBL at various concentrations for $1 \mathrm{~h}$, as indicated in Figures 3 and 4. In these figures, a dose dependent inhibitory effect on colony formation in both cells lines can observed, being Sw480 cells lines more sensitive (84\% inhibition) than C33-A cells (58\% inhibition).

Figure 3. Inhibitory effect of tepary bean lectin on colony formation of the human colon cancer cell line (Sw480). Cells were exposed to the indicated concentration of lectin for $1 \mathrm{~h}$. Then the number of cells that were able to form colonies was determined as described in the Experimental section. Results are presented as the percentage of the inhibition of colony formation. Each value represents the mean $( \pm \mathrm{SD})$ obtained from triplicate plates.

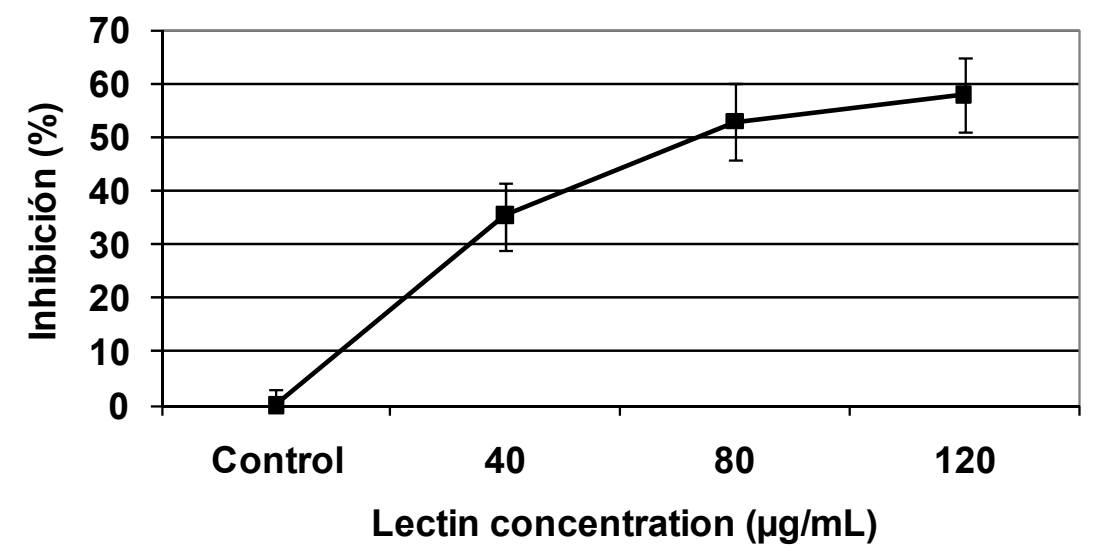


Figure 4. Inhibitory effect of tepary bean lectin on colony formation of the human epithelial cervical carcinoma cell line (C33-A). Cells were exposed to the indicated concentration of lectin for $1 \mathrm{~h}$, then the number of cells that were able to form colonies was determined as described in the Experimental section. Results are presented as the percentage of the inhibition of colony formation. Each value represents the mean $( \pm \mathrm{SD})$ obtained from triplicate plates.

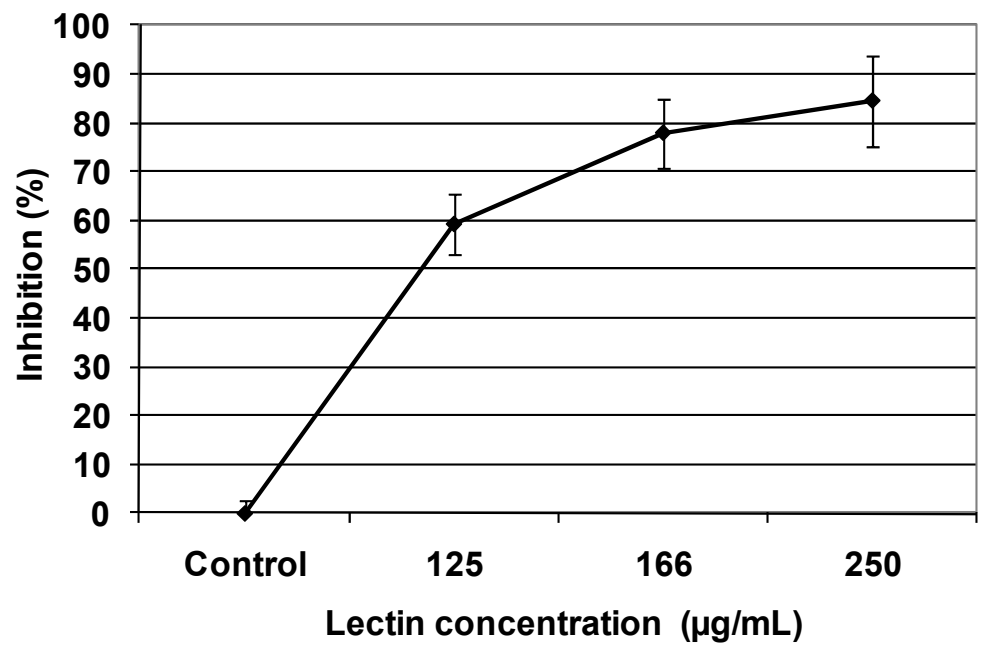

\subsection{Discussion}

Today the main problem in the use of drugs in cancer treatment is the potential toxicity of these agents to normal cells; for this reason chemoprevention employing natural agents for the treatment and prevention cancer is a good and new alternative. For this reason since several years ago, studies that analyze the anticarcinogenic activity of many plants extracts or pure phytochemical compounds have been reported [31,32]. Some of these studies, performed in vitro and in vivo, have shown that phytochemical compounds have the capacity to inhibit the viability of malignant cells as well as the growth of tumors in animals $[33,34]$. Some of these compounds are proteins such as lectins, and there is plenty of evidence that pure lectins, or protein extracts enriched with these proteins possess cytotoxic effects in normal or malignant cells from different origins [19,35]. For this reason in the present work, tepary bean lectin was purified with the aim of studying its anticarcinogenic potential on human malignant cells lines such as of colon cancer (Sw480) and cervical cancer (C33-A).

Our results show that tepary bean lectin has cytotoxic effects on both malignant cells lines, evidenced by a decrease in the cellular viability of approximately $30 \%$ and $90 \%$, respectively (Figure 2); as well as an inhibitory effect on DNA synthesis, shown by a decrease in ${ }^{3}[\mathrm{H}]$-tymidine incorporation to $67 \%$ for Sw 480 cells and $57 \%$ for C33-A cells after 24 hours.

Colony formation assays confirmed the TBL effect on the proliferation of both cells lines; being this effect higher on Sw480 cells (98\%) than in C33-A cells (59\%). This effect increased over several cell cycles. Many reports have suggested that the inhibition of nucleic acid synthesis in tumor cells by lectins is a likely cause for their cytotoxic effect on normal as well in malignant cells $[8,9]$.

The differences observed by this study on the effect of tepary bean lectin on the viability and proliferation of Sw480 and C33-A cells can be explained by variations in the carbohydrate composition on the membrane surface between these cell lines [36,37]. 
Many reports have demonstrated that plant lectins have other effects in tumor cell recognition, cell adhesion and localization, signal transduction across membranes, mitogenic stimulation, apoptosis and citotoxicity $[15,26]$. Other research groups have demonstrated differences in the binding pattern of lectins to malignant cells [10]. Additionally, the anticancer effect of lectins has been documented [26,27,38,39]. Lectins have different toxic capabilities on malignant and normal cells and this differences can be explained due to the presence of different carbohydrate structures on the surface membranes among these cells $[15,40]$.

\section{Experimental}

\subsection{Extraction and purification of lectins}

Tepary bean (Phaseolus acutifolius) seeds were purchased in a local market in Hermosillo (Sonora, México). The beans were ground in a Wiley mill fitted with a 60 mesh screen. The tepary lectin was extracted as described by González de Mejía et al. [41]. The flour was extracted during $16 \mathrm{~h}$ at $4{ }^{\circ} \mathrm{C}$ with $10 \mathrm{mM}$ phosphate buffered saline PBS solution at a 1:10 (w/v) flour:buffer ratio. The mixture was centrifuged at 12,000 $\mathrm{g}$ for $30 \mathrm{~min}$ to remove the insoluble residues; the supernatant was then subjected to a protein precipitation with $70 \%\left(\mathrm{NH}_{4}\right)_{2} \mathrm{SO}_{4}$. After centrifugation at $12,000 \mathrm{~g}$, the precipitate was resuspended and dialyzed overnight against PBS buffer and stored at $-20{ }^{\circ} \mathrm{C}$. The dialysis fraction was subjected to affinity chromatography in a FPLC system (Amersham Biosciences) fitted with a fetuinagarose column. After injection, the unbound material was eluted with 20 volumes of PBS and the bound protein fraction was eluted from the column with 20 volumes of $50 \mathrm{mM}$ glycine- $\mathrm{HCl}, \mathrm{pH} 2.5$. The fractions that were active in the hemagglutination assay (see below), were pooled and dialyzed against distilled water at $4^{\circ} \mathrm{C}$ and subsequently freeze-dried.

\subsection{Quantification of protein}

The protein concentration was determined by the method of Lowry et al. [42] using bovine serum albumin as standard.

\subsection{Hemagglutination assays}

The hemagglutination activity assay was carried out in 96 well microtiter plates. The fetuin bound lectin was diluted serially (2-fold), adjusting the sample volume in each well to $50 \mu \mathrm{L}$ with PBS. Diluted samples were mixed each with $50 \mu \mathrm{L}$ of the $2 \%$ suspension of trypsinized human erythrocytes type $\mathrm{A}$ and $\mathrm{O}$. The reaction mixtures were incubated $1 \mathrm{~h}$ at room temperature and then observed visually for positive agglutination. The titer was defined as the reciprocal of the highest dilution showing detectable agglutination [43].

\subsection{Polyacrilamide gel electrophoresis (PAGE)}

The purified lectin was subjected to electrophoretic analysis by native PAGE under alkaline conditions in an 11\% gel according to the method of Laemmli [44]. After being loaded into the gel, the protein samples were electrophoresed at a constant current of $20 \mathrm{~mA}$ at $4{ }^{\circ} \mathrm{C}$. For dissociation of the 
protein subunits, sodium dodecyl sulfate (SDS) PAGE was carried out according to the method by Laemmli [44] under reducing conditions (with $\beta$-mercaptoethanol) in a $12 \%$ gel. Native and reducing SDS PAGE runs were performed in a vertical mini protean II electrophoretic system (BioRad). Separated proteins in the gels were visualized by staining with Coomasie brilliant blue R-250.

\subsection{Cell culture}

Cytotoxicity assays described bellow were carried out using two human malignant cells lines, Sw480 (human, Caucasian, colon, adenocarcinoma) and C33-A (human epithelial cervical carcinoma). These cell lines were obtained from the American Type Culture Collection (ATCC, Rockville, MD, USA). The cells were grown in Dulbecco's modified Eagle's medium (DMEM) (Gibco, Grand Island, NY, USA), supplemented with $10 \%$ fetal bovine serum (FBS, Gibco) in a $\mathrm{CO}_{2}$ water jacketed incubator (Nuaire, Plymouth, MN, USA) at $37{ }^{\circ} \mathrm{C}$ in humidified atmosphere consisting of $5 \% \mathrm{CO}_{2}$ and $95 \%$ air.

\subsection{Cell viability assay}

The tetrazolium dye colorimetric test using (3-(4, 5-dimethylthiazol-2-yl)-2-5-diphenyltetrazolium bromide (MTT) was used to determinate the viability of Sw480 and C33-A cells lines. The MTT assay is based on the ability on functional mitochondria to catalyze the reduction of (3-(4, 5-dimethylthiazol2-yl)-2-5-diphenyltetrazolium bromide to an insoluble formazan product, the concentration of which can be measured spectrophotometrically [45]. Sw480 and C33-A cells lines were first cultured in 96 well microplates $\left(1.0 \times 10^{4}\right.$ cells/well $)$ in DMEM for $24 \mathrm{~h}$. After incubation, cells were washed twice with PBS, and pretreated with different concentration (0 to $400 \mu \mathrm{g} / \mathrm{mL}$ ) of TBL. After 24 hours of incubation with the lectin solution, the cells were washed with PBS and each well was added with MTT reagent $(5 \mathrm{mg} / \mathrm{mL})$, and the plate was incubated at $37{ }^{\circ} \mathrm{C}$ for an additional $3 \mathrm{~h}$. After this cuncubation, media was removed, and the intracellular formazan product was dissolved in $100 \mu \mathrm{L}$ dimethyl sulfoxide (DMSO). The absorbance of each well was then measured at $540 \mathrm{~nm}$, and the percentage of cell viability was calculated.

\subsection{Cytotoxicity assay}

For the cytotoxicity assays, the cells were cultured in flat bottomed plates at a concentration of $5 \times 10^{4}$ cells/well and incubated with different TBL concentrations ( 0 to $100 \mu \mathrm{g} / \mathrm{mL}$ ) in DMEM for $24 \mathrm{~h}$. The cell proliferation was measured by detecting the incorporation of tritium labeled thymidine ( $3 \mu \mathrm{Ci} /$ well) during an incubation period of $30 \mathrm{~min}$. To stop uptake of radioactivity, the medium was removed and the cells were washed twice with $10 \mathrm{mM}$ PBS solution $\mathrm{pH}$ 7.6. The cells were then lysed by adding $500 \mu \mathrm{L}$ of SDS $0.1 \%$ containing $10 \mathrm{mM}$ EDTA ( $\mathrm{pH} \mathrm{7.4)}$ to each well. After $30 \mathrm{~min}$ of incubation at room temperature, the lysate was added with $500 \mu \mathrm{L}$ of $10 \%$ cold trichloroacetic acid (TCA) and the precipitate was collected in a nitrocellulose paper, washed three times with TCA 5\%, dried, added with scintillation cocktail $(4 \mathrm{~mL})$ and counted in a liquid scintillation counter (Beckman LS 65000). All determinations were done in triplicate. 


\subsection{Colony formation assay}

To examine the effect of TBL on tumor cell colony formation, Sw480 and C33-A cells lines were cultured in $100 \mathrm{~mm}$ Petri dishes at $2 \times 10^{4}$ cells per dish with $10 \mathrm{~mL}$ DMEM medium. After two days, different concentration of tepary bean lectins (C33-A: 0 to $120 \mu \mathrm{g} / \mathrm{mL}$; Sw480: 0 to $250 \mu \mathrm{g} / \mathrm{mL}$ ) were added and incubation continued for $1 \mathrm{~h}$, cultures were the trypsinized ( $0.05 \mathrm{M}$ trypsin), counted and 200 cell were seeded in $60 \mathrm{~mm}$ Petri dishes for determination of colony formation. At least three replicate colony determinations were made for each culture. After 10 days of incubation, the resulting colonies were rinsed with $50 \mathrm{mM}$ phosphate buffer, $\mathrm{pH} 7.6$ containing $150 \mathrm{mM} \mathrm{NaCl}$, fixed with methanol, stained with Giemsa (Sigma) and the number of colonies (with diameter $>0.05 \mathrm{~mm}$ ) per dish were determined as described previously [46]. Inhibition is defined as the ratio of the colony numbers in the treated group to that in the control group.

\section{Conclusions}

In conclusion, the present study has shown that tepary bean (Phaseolus acutifolius) lectin has the ability to inhibit the growth of cancer cells, either by causing cytotoxic or anti-proliferative effects on both the cells lines investigated, and by inhibiting colony formation, being the effects of the lectin more pronounced on Sw480 cells than in C33-A cells. It is known that lectins recognize carbohydrates, and in previous studies with cells, it as come to be known that lectins interact with the carbohydrates present in the external membrane of the cells, and that this bond forms a covalent link; thus, the bond causes cellular modifications, affecting metabolism, cellular division, etc. On the other hand, this lectin could be a candidate to study further for its use in the treatment and prevention of cancer, with different normal and cancerous cell lines, in vivo studies, toxicity studies, etc.

\section{References}

1. Gazdar, A.F.; Girard, L.; Lockwood, W.W.; Lam, W.L.; Minna, J.D. Lung Cancer Cell Lines as Tools for Biomedical Discovery and Research. J. Natl. Cancer Inst. 2010, 102, 1310-1321.

2. Issah, F.; Maree, J.E.; Mwinituo, P.P. Expressions of cervical cancer-related signs and symptoms. Eur. J. Oncol. Nurs. 2010, in press.

3. Pramateftakis, M.G.; Kanellos D.; Vrakas, G.; Tsachalis, T.; Raptis, D.; Makrantonakis, A.; Koukouritaki, Z.; Kanellos, I. Progress in rectal cancer staging and treatment. Tech. Coloproctol. 2010, 14, 529-531.

4. Bishayee, A.; Háznagy-Radnai, E.; Mbimba, T.; Sipos, P.; Morazzoni, P.; Darvesh, A.S.; Bhatia, D.; Hohmann, J. Anthocyanin-rich black currant extract suppresses the growth of human hepatocellular carcinoma cells. Nat. Prod. Commun. 2010, 5, 1613-1618.

5. Qiu, W.; Wang, X.; Leibowitz, B.; Liu, H.; Barker, N.; Okada, H.; Oue, N.; Yasui, W.; Clevers, H.; Schoen, R.E.; Yu, J.; Zhang, L. Chemoprevention by nonsteroidal anti-inflammatory drugs eliminates oncogenic intestinal stem cells via SMAC-dependent apoptosis. Proc. Natl. Acad. Sci. USA 2010, 107, 20027-20032.

6. Dragsted, L.; Srube, M.; Larsen, J. Cancer-protective factors in fruits and vegetables: Biochemical and biological background. Pharmacol. Toxicol. 1993, 72, 116-135. 
7. Pezzuto, J. Plant-derived anticancer agents. Biochem. Pharmacol. 1996, 53, 121-133.

8. Abdullaev, F.I.; Frenkel, G.D. Effect of saffron on cell colony formation and cellular nucleic acid and protein synthesis. BioFactors 1992, 3, 201-204.

9. Abdullaev, F.I.; MacVicar, C.; Frenkel. G.D. Inhibition by selenium of DNA and RNA synthesis in normal and malignant human cells in vitro. Cancer Lett. 1992, 65, 43-49.

10. Abdullaev, F.I.; Rivera-Luna, R.; García-Carranca, A.; Ayala-Fierro, F.; Espinosa-Aguirre, J.J. Cytotoxic effect of three arsenic compounds in HeLa human tumor and bacterial cells. Mutant Res. 2001, 493, 31-38.

11. Pustai, A.J. Plat Lectins; Cambridge University Press: Cambridge, UK, 1991; p. 253.

12. Drikarmer, K.; Taylor, M.E. biology of animal lectins. Annu. Rev. Cell. Biol. 1993, 9, 237-264.

13. Gabius, H.J. Animal lectins. Eur. J. Biochem. 1997, 243, 543-576.

14. Wong, J.H.; Ng, T.B.; Cheung, R.C.; Ye, X.J.; Wang, H.X.; Lam, S.K.; Lin, P.; Chan, Y.S.; Fang, E.F.; Ngai, P.H.; Xia, L.X.; Ye, X.Y.; Jiang, Y.; Liu, F. Proteins with antifungal properties and other medicinal applications from plants and mushrooms. Appl. Microbiol. Biotechnol. 2010, 87, 1221-1235.

15. Sharon, N.; Lis, H. Lectin-proteins with a sweet tooth: Functions in cell recognition. Assays Biochem. 1995, 30, 59-75.

16. Goldstein, I.J.; Hughes, R.S.; Monsigny. M.; Osawa, T.; Sharon, N. What should be called a lectin? Nature 1980, 285, 665-666.

17. Sabová, L.; Pilátová, M.; Szilagyi, K.; Sabo, R.; Mojzis, J. Cytotoxic effect of mistletoe (Viscum album L.) extract on Jurkat cells and its interaction with doxorubicin. Phytother. Res. 2010, 24, 365-368.

18. Li, C.Y.; Xu, H.L.; Liu, B.; Bao, J.K. Concanavalin A, from an old protein to novel candidate anti-neoplastic drug. Curr. Mol. Pharmacol. 2010, 3, 123-128.

19. Matsuda, A.; Kuno, A.; Kawamoto, T.; Matsuzaki, H.; Irimura, T.; Ikehara, Y.; Zen, Y.; Nakanuma, Y.; Yamamoto, M.; Ohkohchi, N.; Shoda, J.; Hirabayashi, J.; Narimatsu, H. Wisteria floribunda agglutinin-positive mucin 1 is a sensitive biliary marker for human cholangiocarcinoma. Hepatology 2010, 52, 174-182.

20. Kaur, M.; Singh, K.; Rup, P.J.; Saxena, A.K.; Khan, R.H.; Ashraf, M.T.; Kamboj, S.S.; Singh, J. A tuber lectin from Arisaema helleborifolium Schott with anti-insect activity against melon fruit fly, Bactrocera cucurbitae (Coquillett) and anti-cancer effect on human cancer cell lines. Arch. Biochem. Biophys. 2006, 445, 156-165.

21. Blonski, K.; Schumacher, U.; Burkholder, I.; Edler, L.; Nikbakht, H.; Boeters, I.; Peters, A.; Kugler, C.; Horny, H.P.; Langer, M.; Wilhelm-Ogunbiyi, K.; Witthohn, K.; Laack, E. Binding of recombinant mistletoe lectin (aviscumine) to resected human adenocarcinoma of the lung. Anticancer Res. 2005, 25, 3303-3307.

22. Nozoe, T.; Korenaga, D.; Ohga, T.; Futatsugi, M.; Machara, Y. Suppression of the phytohemagglutinin response to lymphocytes is an independent prognosticator in patients with squamous cell carcinoma of the esophagus. Ann. Thorac. Surg. 2003, 76, 260-265.

23. Valentiner, U.; Ian, S.; Schumacher, U.; Leathem, A.J. the influence of dietary lectins on the cell proliferation of human breast cancer cell lines in vitro. Anticancer Res. 2003, 23, 1197-1206. 
24. Gastman, B.; Wang, K.; Han, J.; Zhu, Z.Y.; Huang, X.; Wang, G.Q.; Rabinowich, H.; Gorelik, E. A novel apoptotic pathway as defined by lectin cellular initiation. Biochem. Biophys. Res. Commun. 2004, 26, 263-271.

25. Banchonglikitkul, C.; Smart, J.D.; Gibbs, R.V.; Donovan, S.J.; Cook, D.J. An in vitro evaluation of lectin cytotoxicity using cell lines derived from the ocular surface. J. Drug. Target. 2002, 10, 601-606.

26. Janssen, O.; Scheffler, A.; Kabelitz, D. In vitro effects of mistletoe extracts and mistletoe lectins. Cytotoxicity towards tumor cells due to the induction of programmed cell death (apoptosis). Arzneimittelforschung 1993, 43, 1221-1227.

27. Schwarz, R.E.; Wojciechowicz, D.C.; Picon, A.I.; Schwarz, M.Z.; Paty, P.B. Wheatgerm agglutinin-mediated toxicity in pancreatic cancer cells. J. Cancer 1999, 80, 1754-1762.

28. Kiss, R.; Camby, I.; Duckworth, C.; De Decker, R.; Salmon, I.; Pasteel, J.L.; Danguy, A.; Yeaton, P. In vitro influence of Phaseolus vulgaris, Griffonia simpliciflia, oncanavalina A, Wheat germ, and peanut agglutinin on HCT-15, Lovo, d SW 837 human colorectal cancer cell growth. Gut 1997, 40, 253-261.

29. Hammar, L.; Hirsch, I.; Machado, A.A.; De Mareuil, J.; Baillon, J.G.; Bolmont, C.; Chermann, J.C. Lectin-mediated effects on HIV type I infection in vitro. AIDS Res. Hum. Retrovir. 1995, 11, 87-95.

30. Ito, T.; Suzuki, Y.; Mitnaul, L.; Vines, A.; Kida, H.; Kawaoka, Y. Receptor specificity on influenza A viruses correlates with the agglutination of erythrocytes from different animal species. Virology 1997, 227, 493-499.

31. Efferth, T. Cancer therapy with natural products and medicinal plants. Planta Med. 2010, 76, 1035-1036.

32. Gullett, N.P.; Ruhul Amin, A.R.; Bayraktar, S.; Pezzuto, J.M.; Shin, D.M.; Khuri, F.R.; Aggarwal, B.B.; Surh, Y.J.; Kucuk, O. Cancer Prevention with Natural Compounds. Semin. Oncol. 2010, 37, 258-281.

33. Ojeswi, B.K.; Khoobchandani, M.; Hazra, D.K.; Srivastava, M.M. Protective effect of Thuja occidentalis against DMBA-induced breast cancer with reference to oxidative stress. Hum. Exp. Toxicol. 2010, 29, 369-375.

34. Tayarani-Najaran, Z.; Mousavi, S.H.; Asili, J.; Emami, S.A. Growth-inhibitory effect of Scutellaria lindbergii in human cancer cell lines. Food. Chem. Toxicol. 2010, 48, 599-604.

35. Zhou, X.X.; Ji, F.; Zhao, J.L.; Cheng, L.F.; Xu, C.F. Anti-cancer activity of anti-p185HER-2 ricin A chain immunotoxin on gastric cancer cells. J. Gastroenterol. Hepatol. 2010, 25, 1266-1275.

36. Behnckern, A.; Saeger, W. Lectin Binding in pituitary Adenoma and Normal Pituitaries. Phat. Res. Pract. 1991, 187, 629-631.

37. Damjanou, I.; Sobrinho-Simoes, M. Lectin Histochemistry of Human Thyroid Tumors. In Lectins and Cancer; Gabius, S., Gabius, H.J., Eds.; Springer-Verlag: Berlin, Germany, 1991; pp. 41-52.

38. Bardocz, S.; Grant, G.; Duguid, T.J.; Brown, D.S.; Pusztai, A.; Pryme, I.F. Effect of phytohaemoagglutinin on the growth of Krebs II tumour cells, body metabolism and internal organs of mice. Int. J. Oncol. 1994, 5, 1369-1374.

39. Pryme, I.F.; Bardocz, S. Anti-cancer therapy: Diversion of polyamines in the gut. Eur. J. Gastroen. Hepatol. 2001, 13, 1041-1046. 
40. Miller, J.B.; Noyes, C.; Heinrikson, R.; Kingdon, H.S.; Yachnin, S. Phytohemagglutinin mitogenic proteins. Structural evidence for a family of isomitogenic proteins. J. Exp. Med. 1973, 138, 939-951.

41. González de Mejía, E.; Grajeda Cota. P.; Celada, E.; Valencia, M.E. Characterization of the nutritional potential of tepari bean (Phaseolus acutifolius) grown in Mexico. Arch. Latinoam. Nutr. 1988, 38, 907-924.

42. Lowry, O.H.; Rosebrough, J.N.; Fan, A.; Randall, R.J. Protein measurement with the folin phenol reagent. J. Biol. Chem. 1951, 193, 265-275.

43. Jaffe, W.G.; Brucher, O.; Palozzo, A. Detection of tour types of specific phytohemagglutinins in different lines of beans (Phaseolus vulgaris) Z. Immun. Forsh. Bd. 1972, 142, 439-447.

44. Laemmli, V.K. Cleavage of structural protein during the assembly of the head of bacteriophage $t 4$. Nature 1970, 227, 680-685.

45. Hansen, M.B.; Nielsen, S.E.; Berg, K. Re-examination and further development of a precise and rapid dye method for measuring cell growth/cell kill. J. Immunol. Methods 1989, 119, 203-210.

46. Abdullaev, F.I.; Gonzalez de Mejia, E. Inhibition of colony formation of Hela cells by naturally occurring and synthetic agents. Biofactors 1996, 5, 133-138.

Sample Availability: Samples of the compounds are available from the authors.

(C) 2011 by the authors; licensee MDPI, Basel, Switzerland. This article is an open access article distributed under the terms and conditions of the Creative Commons Attribution license (http://creativecommons.org/licenses/by/3.0/). 